\title{
ASPECTOS DE DIREITO PÚBLICO ROMANO: As Constituições Políticas da Realeza e da República
}

\author{
Eduardo Cesar Silveira Vita Marchi
}

Resumo:

Breve síntese de Direito Público Romano, vale dizer, de história externa do Direito Romano, com a exposição da constituição política - órgãos de representação e comando político e judiciário da civitas -.. durante a Realeza e a República.

Palavras-chave: Direito Romano. História do Direito Romano. Realeza. República.

\begin{abstract}
:
Brief outline of the Roman Public Law, namely of the so-called external history of Roman Law, with a delineation of the political constitution that is to say, the organs of political representation as well as those of political rule and for the administration of justice ir: the civitas - during the monarchic and republican periods of Roman history.
\end{abstract}

Keywords: Roman Law. History of the Roman Law. Monarchy. Republic.

\section{Fundação (Lendária) de Roma}

Derrotada Tróia pelos grcgos, com a cidade ainda em chamas, o herói troiano Enéias, filho de Anquises e da deusa Vênus, acompanhudo por seu pai e pelo pequeno filho Iulo, sai em retirada, vindo a aportar na Itália.

No Lúcio, após uma disputa de morte contra Turno, rei dos Rútulos, pela mão da princesa Lavinia, filha do rei dos Latinos, outro povo local, Enéias consegue esposá-la. Tempos depois, Iulo, seu filho, funda Alba Longa, assim chamada pela disposição topográfica em longa fileira de suas casas.

Passado algum tempo, estando-se já no séc. VIIl a.C., um dos descendentes de Enéias e Iulo, chamado Númitor, mediante uma conspiração, é destronado de Alba Longa por seu irmão, Amúlio. Este, após matar os filhos de Númitor, obriga Rea Silvia, a sohrinha e únicu filhu-mulher do irmão, a ingressar na ordem das Vestais.

Tal ordem cru consagrada ao culto da deusa Vesta, sendo suas sacerdotisas

Escopo do presente artigo é o de servir de instrumento didático e de divulgação histórico-cultural; por conta disto, prescindiu-se das notas de rodapé, comprovatórias das fontes primárias e da bibliografia de base.

- Professor Titular de Direito Romano do Departamento de Direito Civil da Faculdade de Direito da Universidade de São Paulo. Diretor da Faculdade de Direito da Universidade de São Paulo. 
inteiramente proibidas de casar, sob pena de condenação à morte na forma cruel do emparedamento ou do sepultamento com vida. Rea Silvia, todavia, í engravidada pelo deus Murke, dundo ì luz dois gèmeos, chamados de Rômulo e Remo.

Fim segrida à condenação e morte de Rea Silvia, Amúlio ordena que os gêmeos sejam jogados no Rio Tibre. O executor, toduvia, por compaixão, coloca-os sobre as águas protegidos dentro de um iesto, e os abandona. O cesto com os dois gèmeos, após vagar à deriva, encalha entre os caniços de um ponto da margem.

São, então, encontrados por uma loba que, ao invés de devorá-los, os carrega à Colina do Palatino. passando a amamentá-los. Mais tarde, são eles incontrados e recolhidos pelo pastor Faustulo, que os educa e os cria como filhos.

Adultos, Rômulo e Remo, após descobrir a verdade, retornam a Alba Longa, e, com o apoio da população, destituem e matam o tio usurpador Amúlio, recolocando no trono o avô Númitor. Este, por sua vez, concede em doação aos dois uma área na margem esquerda do Tibre, nas proximidades do local onde a cesta enculhara. Os dois irmãos ali se instalam.

Fra o dia 21 de abril de 754 a.C. Disputando-se entre eles a primazia de dar o próprio nome à cidade, Rômulo vence o irmào Remo, o qual, despeitado da vitória do primeiro, o desafia e o ameaça, sendo por ele morto.

Roma, a Cidade Eterna, está fundada.

Esta é a lenda, transmitida a nós pelos autores latinos, especialmente os historiógrafos Tito Livio, originário de Patavium, atual Pádua (daí a expressão "não entendo patavina". com referência ao latim liviano), Dionísio de Halicarnasso. e poetas como Homero e Virgílio. Tais autores latinos, vivendo a mais de sete séculos de distância dos acontecimentos narrados, haviam colhido tal lenda através da tradição ou narração oral passada de geração a geração.

É evidente que tal lenda, nos seus contornos gerais, ć fantasiosa. Ao fazer derivar, por exemplo, a origem dos romanos da gloriosa história da Grécia, reflete, aliás, uma característica e um sentimento típicos do ser humano. comum também ao homem modemo: procurar sempre enaltecer a própria descendência e estirpe.

No entanto. a mudema ciência histórica, ao tentar interpretar tais lendas transmitidas oralmente, percebeu existir $\mathrm{em}$ todas elas, a rigor, um fundo de verdade.

Tal se justificaria com base no próprio tipo de transmissão dos acontecimentos. feito por meio oral: ainda hoje, por exemplo, um simples acidente entre dois veículos de pequeno porte, com leves ferimentos em uma vítima, pode, após algum tempo, feita a transmissão boca-a-boca dos fatos, transformar-se em uma fantasiosa e trágica ocorrência entre dois grandes veículos, com a morte violenta da vítima. Resta sempre, contudo, o fundo 
de verdade. Houve um acidente, mas não com os contornos finais exagcradamente acrescentados.

Assim também devi ser interpretada a lenda da fundação de Roma.

Neste sentido, é provável, por exemplo, como apontam os estudiosos, que a lide entre Rômulo e Remo tenha, na verdade, consistido, nos primórdios, em uma luta entre duas aldeias ou duas populações locais do antigo Lácio, os Latinos e os Sabinos, assentados na zona central da península itálica. pelo poder da nova aldeia que surgia. Ambos. talvez. haviam anteriormente se unido para combater o povo dos Etruscus. Iocalizado mais ao norte, na área correspondente à atual Toscana. Neste sentido, sob outra análise, o confronto entre Rômulo e Remo poderia ainda simbolizar uma guerra entre os Etruscos e os aliados Latinos e Sabinos.

Dificil ou quase impossível saber-se a verdade, uma vez que, não tendo chegado diretamente até nós documentos ou material deste longínquo e lendário período, permanece-se fora em termos técnicos daquilo que convencionalmente costumamos chamar “época histórica” (cm Roma, a partir aproximadamente do séc. V a.(.).

O principal instrumento dos estudiosos na comprovação científica desta tese do "fundo de verdade" tem sido, além da Filologia, principalmente a Arqueologia.

Recorde-se neste sentido. por exemplo. que até o séc. XVIII e, portanto. durante toda a Idade Média e Renascimento. o relato das fontes latinas (especialmente o de Plinio, o Jovem) concernente à existência c depois trágica morte de Pompéia e Herculano. destruídas pela erupção do Vesúvio, era tratado como mais uma lenda de época romana até que, naquele século, em uma planiação nos arrudores de Nápoles, aflorou a ponta de uma das altas paredes do anfiteatro pompeiano sepultado há séculos. A "lenda” era verdadeira!

Algo semelhante também ocorreu, em época relativamente recente, em relação à lenda da fundação de Roma.

Escavações e pesquisas arqueológicas na Roma atual, na área conhecida por Forum Olitorium ou Boarium, possivel antigo mercado de hortaliças e gado (e daí a sua denominação em latim), localizado entre a colina do Campidólio e o Rio Tibre, trouxeram à luz cerâmicas provenientes justamente da Grécia: examinadas por especialistas em história da arte antiga, foram elas datadas. por comparação com outras encontradas na Macedônia. exatamente na mesma época indicada pela "lenda" isto é, por volta de meados do sćculo VIII a.C.!

Assim sendo. em resumo, é bem provável, como diz a lenda, que por volta de 754 a.C. tenha surgido uma pequena aldeia no local acima descrito, a qual viria a conquistar o mundo.

Com toda probabilidade ter-se-ia tratado de um entreposto comercial, 
freqüentado tanto pelos povos vizinhos (etruscos, latinos. sabinos etc.) quanto também, certamente, dada aquela comprovação arqueológica, pelos gregos.

Por outro lado, uma análise mais detida das características topográficas e gcográficas do local onde teria nascido Roma trouxe, também, aos estudiosos a comprovação de que tal áréa não fôra escolhida por puro acaso: cuida-se de um local com posição topográfica privilegiadíssima, com vales e passagens naturais que ali desembocam, e com a presença do Tibre, perto (vinte quilômetros) de sua foz no Mar Mediterrâneo.

Todas estas características contribuíram para o surgimento ali de um ponto central de cruzamento de vias naturais, e, por conseqüência, um excelente espaço para a instalação de um entreposto comercial.

Em conclusão: a história de Roma começa, de fato, comprovadamente, em meados do século VIII a.C.

Passemos à exposição dos períodos históricos ou fases de desenvolvimento das Constituições políticas da antiga Roma, isto é. das instituições público-políticas da experiência romana de treze séculos.

A divisão destas fases ou períodos costuma ser feita, convencionalmente, com base na diversa organização política: Realeza ou Monarquia (da fundação de Roma, em 754 a.C. até a expulsão dos reis, em 510 a.('), República (de 510 a.C. até a ascensão do primeiro imperador, Augusto, em 27 a.C.), Principado ou Alto Império (de 27 a.C. até Diocleciano, em 284 d.C.), e, finalmente, a Monarquia Absoluta ou Baixo Império (de 284 d.C. até a morte de Justiniano, em 565 d.C.).

Após Justiniano, também convencionalmente. tem início no Ocidente a história individual dos ordenamentos jurídico-públicos das futuras naçôes européias, e no Oriente. começa o chamado Império Bizantino.

Advirta-se, já de início. que esta divisão do estudo por períodos, com fundamento em uma exata indicação do ano ou do acontecimento histórico, é inteiramente artificiosa, justificando-se apenas como recurso didático. Em outros termos, é ela, pois, como se disse, puramente convencional, servindo apenas como ponto de orientação geral.

$\mathrm{Na}$ verdade. como se sabe, as passagens entre os grandes períodos históricos geralmente não ocorreram da noite para o dia, mas lentamente, com base em certas mudanças paulatinas da realidade, as quais, agrupadas por suas reconheciveis linhas gerais, possibilita a divisão do estudo por períodos históricos.

Em comparaçâo com os tempos atuais, na recente história política brasileira, é o que se deu na passagem entre a Ditadura militar iniciada nos anos 60 , c o regime democrático hoje cm vigor. Aliás, em comprovação àquela idéia, há ainda quem sustente, entre nós, não ter-se tal processo de transição ainda se concluído totalmente. 


\section{Realeza (754 a.C, 510 a.C.)}

Segundo a tradição, o primeiro rei, Rômulo, concebe e organiza a propricidac privada, distribuindo dois lotes (bina iugera) de t'rreno para cada morador (com úrca tot. cada um. pois, de $16.704 \mathrm{~m}^{2}$, já que' l iugerum correspondia a 28.800 pés quadrados, val: dizer, $8.3 .52 \mathrm{~m}^{2}$ ).

() segundo, Numa Poimpilio, um Sabino, dá a Roma sua religião, divide o ano em doze meses, ' 'riji' um Templo ao Deus Juno. O terceiro, Túlio Hostílio, enérgico militar, cria as normas da guerra, e arrasa Alba Longa. O quarto, Anco Márcio, rei sábio e pacificu. dedica-se às obras púhlicas, melhorando as vias naturais de comunicação (construção do Porto de Óstia e da Punte Sublicio) e aumentando o poder central (construção do cárcen' Mumertino) da organização política representada pela cidade-Estado (civitas) defronte uos mícleos ou grupos farniliares (gentes).

Seguem-se os últimos três reis, todos etruscos. O primeiro, Turquinio Prisio, após derrotar os Latinos e os Sabinos, continua as obras de infra-estrutura da cidade, iniciadas pelo seu antecessor, construindo a ricde de águas (aquedutos) c' esgosto (c loaca Máxima), a praça central, coração da vida politica, judiciária ' comercial da (idade (Fórum), e um estádio para as atrações de lazer (Circo Máximo). O segundo, Sérvio Túlin. manda cunhar a moeda, amplia a cidade, constrói novas muralhas, e organiza o povo cm centúrias. Finalmente, o terceiro, Tarquinio, o Soberbo, revela-se um tirano, manda matar muitos cidadãos e senadores, provocando geral descontentamento no povo romano. que. rebelado, expulsa o último rei de Roma. instituindo a República. O ápice da revolta contra Tarquinio, segundo a lenda, residiu no estupro praticado por Sexto, seu filho, contra I.ucrécia, matrona romana, que, marcada duplamente pela desonra sofrida é pela desconfiança do marido, opta pelo suicidio.

Ressaltem-se, neste relato lendário, principalmente três aspectos.

Em primeiro lugar, parece restar claro a influência exercida pelo povo etrusce na formação originária de Roma. A transformação da pequena aldeia no lado esquerdo do Tibre em um centro urbano, mediante as referidas obras de infra-estrutura da cidade, deverja, segundo muitos autores. ser debitada fundamentalmente aos etruscos. Segundo outros, até mesmo o nome Roma seria etrusco.

Um segundo aspecto diz respcito à história da propriedade privada na Antigüidade.

('om base neste relato lendário, teria ela, pois, no caso de Roma, surgida ao tempo do primeiro Rui, Rômulo, quando do início da cidade (civitas).

Antes deste surgimento, todavia. não é possivel, como querem alguns, 
apresentar-se a questão sobre se a arcaica propriedade na península itálica fosse coletiva ou privada. Tal problema scria proposto em turmos estranhos à antiga mentalidade, com ela não se coadunando (Biondi). A primitiva propriedade ao tempo das tribos ou grupos gentilícios (gentes), isto é, antes das cidades, tinha um caráter familiar: era a sede na qual a família vivia e trabalhava. Assim sendo, a propriedade não era coletiva, pois não se admitia, àquele tempo, antes da "civitas" igualdade jurídica entre os membros do grupo familiar. Porém. tampouco era privada ou individual, já que se considerava o grupo familiar e não o particular ou individuo. Era, como se disse, a sede do grupo ou da "gens"

Tal representa uma idéia paralela, modernamente. à de "território" no âmbito da teoria geral do Estado: não pertence (todo ele) aos indivíduos ou particulares, mas nem tampouco (todo ele) ao Estado.

Em terceiro lugar, o relato final da expulsão dos reis, no tocante à descrição do estupro de Lucrécia (e seu conseqüente suicídio) por obra do filho de Tarquínio, o Soberbo à parte a questão histórica acerca da real importância de tal evento para a queda da Realeza -, apresenta, nos seus contornos, grande atualidade.

Tem ele conexão com um dos temas marcantes do mundo atual, vale dizer. o assédio sexual contra mulheres. Resulta surpreendente verificar como. passados tantos séculos, pouco tenha-se evoluido, quer nos aspectos jurídicos, quer naqueles antropológicos, neste tema.

O caso de Lucrécia, pelo relato das fontes, poderia ser tratado como um dos primeiros exemplos conhecidos de violência sexual e discriminação contra mulheres (Rizzelli). Como sóe acontecer ainda hoje, são elas duplamente vítimas, primeiro do estupro, e, depois, da desonra representada pela desconfiança masculina quanto à uma eventual anuência ou provocação maliciosa da própria mulher.

De modo cruel, são elas também vítimas da suposição machista de um oferecimento de resistência possivelmente não levada até o limite das forças. Isto pode significar, na prática, uma condenação à morte da própria vítima dusonrada, como o ocorrido no caso de Lucrécia. Calando-se. resta ela desonrada pela violência sexual. Denunciando, é ela novamente ofendida pelo preconceito machista. Não há escapatória.

Triste verificar, por último, neste sentido, que "modemíssimas" legislações em matéria de repressão penal à violência scxual, ao regulamentarem algumas "fattispecie" (como, v.g., a Lei processual-penal italiana n. 66, de 15 de fevereiro de 1996, acerca de tal crime), refletem a mesmíssima realidade ao tempo de Lucrécia: invertem-se os papéis das partes no rito processual, exigindo-se da vítima de estupro a prova da efetiva violência sofrida, não bastando. para a caracterização de crime, a simples falta de consentimento por parte da mulher. De vítima. torna-se cla, um certo sentido, imputada, pois ć a sua conduta que passa a sur investigada. 


\subsection{Constituição política}

A Constituição Politica de Roma, na Realeza ou Monarquia. estruturava-se em três órgãos: o Rei. o Senado e o Povo Romano (Populus Romanus), representado pelas assembléias populares: os Comícios por Cúrias.

O Rei romano era um monarca vitalício, nomeado. ao que parece, pelo antecessor. Reunia poderes religiosos, militares e administrativo-judiciários. Era. portanto, ao mesmo tempo, o sumo sacerdote. supremo chefe militar, principal administrador público e juiz maior. No desempenho destas suas funções, era assistido por alguns auxiliares.

O Senado, por sua vez, ura composto, segundo a tradição, pelos veneráveis anciãos (senes). Constituía na verdade, primitivamente, uma assembléia composta pelos chefes (patres) de cada um dos agrupamentos familiares (gentes). Tinha uma função consultiva em relação ao rei, e confirmatória no tocante às deliberações da assembléia popular.

Quanto ao Populus Romanus, devemos dividir os campos das funções políticopúblicas (assuntos administrativos. judiciários, militares ou de política exterior) e aquele das relações privadas ao interno da familia.

A família romana, em sua estrutura original, segundo conhecida e clássica tese (Scialoia-Bonfante), hoje muito combatida, teria tido, em lempos antigos, antes da formação da civitas, caráter e função política. Seria comparável a um minúsculo Estado, com as suas mesmas características estruturais: a) poder absoluto de um chefe politico, o paterfainilias; b) sujeição total dos seus integrantes; c) tendência a uma maior agregação de membros; d) propriedade fundiária familiar comparável a de um território; e) repugnância ao fracionamento do mesmo.

Por conta disto, na órbita das relações privadas familiares, o paterfamilias era o monarca, sacerdote e juiz doméstico, com poder de vida e morte sobre seus membros (ius vitae ac necis).

Durante a Realeza, estas familias formaram subagrupamentos ou núcleos sociais, que eram de três tipos: as gentes, a clientela e a plebe.

As gentes eram agrupamentos das várias famílias mais ricas e tradicionais, chamados patrícios (patricii ou patres - constituindo, pois, a classe dominante), reunidas por haver (pretensamente) uma descendência ou origem comum.

A clientela (de cliens, "o que deve obedecer"), por sua vez, era constituida por cidadãos romanos de segunda classe, composta. provavelmente, pelas famílias empobrecidas ou originariamente estrangeiras. Constituía uma espécie de vassalagem. submetida ao poder de um chefe de gens em troca de proteção política, judiciária e econômica. 
Por fim, a plebe (plebs).

Ela é fruto de uma essencial transformação sofrida pela antiga civitas em sua composição demográfica. A primitiva cidade, composta em origem apenas pelos agrupamentos familiares patrícios das gentes, vî pouco a pouco o surgimento de um novo grupo ou clemento social, nascido e desenvolvido fora dos agrupamentos gentilícios ("gentes non habent"): é a plebe.

Qual seria a sua origem ou quem scriam estes plebeus?

A resposta é muitissimo dificil, pela falta de documentos advindos diretamente desta época chamada lendária. Existem algumas hipóteses. Estas se fundam em explicações ou pressupostos diversos:

a) possivel divisão étnica originária, sendo patricios os latinos e plebeus os sabinos, ou patrícios os etruscos e plebeus a população latino-sabina;

b) divisão politica ou político-econômica. em que os plebeus seriam antigos povos latinos subjulgados por Roma e agregados à cidade sem escravidão (Niebuhr), ou constituiriam a própria clientela (ou suja, os clientes ou seus descendentes), pouco a pouco desaparecida e transformada na plebe, especialmente com a morte do patrono-patricio sem a continuidade da familia (Mommsen);

c) divisão puramente econômica de classes sociais, constituindo os plebeus uma espécie de proletariado urbano, originário das populaçñes humildes do campo (excolonos), emigradas para a ciclade em busca de trabalho (Bloch), ou representando um extrato social intermediário entre os patrícios e as classes sociais economicamente mais baixas da população (Momigliano), ou seja, uma espécie de classe média.

As hipóteses, como se viu, são muitas. Todavia, deve-se, desde logo, afastar a idéia de que a plebe era composta inteiramente pela população mais pobre da cidade.

Constituía, possivelmente, uma grande massa proletária, parte da qual, contudo. representada por novos-ricos, enriquecidos com as atividadus de comércio e serviços, em uma situação análoga ao que ocorre ainda hoje em certos lugares e em certas épocas. Pense-se, por exemplo, em analogia com a historia local de São Paulo, na origem da atual elite econômica paulista: ele é. em sua maior parte, composta pelos descendentes dos imigrantes aqui aportados (principalmente italianos. libaneses e japoneses).

Fstes novos-ricos compunham. muito provavelmente, em relação às massas plebeias, as suas lideranças, acrescidas, algumas vezes, dos filhos rebeldes de algumas das ricas e tradicionais famílias patricias, tambim em uma situação muito scmelhante ao do mundo moderno (como, por exumplo, no caso da composição da força político-partidária predominante da história política do Brasil dos dias atuais).

De qualquer modo, resta o fato de que, a princípio, os plebeus, apesar de 
viverem dentro das mesmas muralhas e na mesma cidade dos patrícios, eram destes separados, formando um mundo à parte, com suas próprias autoridades (tribunos da plebe), assembléias populares (concílios da plebe), leis (plebiscitos) e religião.

Eles, a princípio, não tinham não tinham quaisquer direitos civis ou políticos, reservados apenas aos patrícios. O poder político, bum como a representação do Estado romano perante outros povos, concentrava-se inteiramente nas mãos dos órgãos patrícios (Rei, Senado e Comícios por Cúrias).

Esta foi a origem dos graves conflitos entre patricios c plebeus, com as acirradas lutas de resistência, greves e rebeliões destes últimos, intensificados e decisivos. como veremos, mais além, na história da República romana.

Saindo do âmbito interno das relações privadas de familia. e adentrando no campo das funções político-públicas. o Populus Romanus, terceiro órgão, como se disse, da Constituição romana da Realeza, era representado pelas assembléias populares-patrícias, isto é, os Comícios por Cúrias.

As Cúrias ('uriae), compostas apenas pelos patrícios, consistiam nas circunscrições político-administrativas mais antigas da civitas. Eram organizadas em assembléias populares, chamadas, por isto mesmo, "Comícios por Cúrias" (comitia curiata). Estes comícios se ocupavam de assuntos político-administrativos, como a incorporação de uma familia (então equiparável, como acima referido, a um grupo político ou miniEstado) a outra (adrogatio) ou a aprovação de testamentos públicos (com a nomeação do puterfamilius herdeiro, vale dizer do novo chefe político deste miniEstado). Segundo alguns, tais assembléias talvez tenham tido também, originariamente, a função de eleger o novo Rei.

Todavia, ao lado dos Comícios por Cúrias ter-se-ia constituído, segundo a tradição lendária já na Realeza, através de uma reforma radical da sua Constituição Política, um novo tipo de assembléia popular, formada com base em diversa circunscrição políticoadministrativa: as Centúrias (centuriae).

Nelas os patrícios eram divididos em seções ou grupos em consonância com a sua riqueza ou fortuna pessoal. Este novo tipo de assembléia teria por funções colaborar no processo de formação das leis. eleger os dirigentes político-administrativos, e apreciar recursos penais de condenados à morte.

A modema crítica histórica, contudo, rechaça uma tal noticia a nós transmitida pelos autores latinos, por entender constituir uma das comuns antecipações históricas de que aqueles se valem para a exposição de fatos ocorridos em época anterior a eles. Os Comícios por Centúrias, na verdade, apesar de terem as suas origens provavelmente em época monárquica. teriam surgido, ou se firmado, com todas as suas funções politico-públicas, apenas na República. 
Resta, por firm, um último aceno à vida privada e pública dos romanos em época monárquica: a Religião.

Neste aspecto, o Estado romano deste periodo poderia ser qualificado. como dizem alguns, como uma perpétua aliança entre os vivos e as forças sobrenaturais, característica, aliás, bastante comum em quase todos os povos do mundo antigo.

Em uma tal situação, é facilmente compreensivel e justificável o grande poder político atribuído aos sacerdotes em geral, e de modo especial ao pontifex maximus, vale dizer, o próprio Rei. Tais sacerdotes eram os depositários do dircito (regras costumeiras e fórmulas processuais), exercendo, nesta área, tumbém atividades de consulta aos litigantes.

\section{República (510 a.C: 27 a.C.)}

De acordo com a tradição lendária, como se disse, em 510 a.C. os romanos teriam conseguido expulsar o último Rei (etrusco) de Roma, tendo início a República, que se estende até a ascensão de Augusto, em 27 a.C.

A data de 510 a.C., recordada pelas fontes, vale como recurso didáticoconvencional.

Não-obstante tal relato possa representar a possível ocorrência de um verdadeiro "golpe de Estado", é inverossímil que as transformações essenciais entre as duas Constituições Políticas (da Realeza e da República) tenham-se verificado, como já se disse anteriormente, em uma data especifica.

Mais provável é que esta fundamental mudança tenha ocorrido paulatinamente no periodo grosso modo entre 510 e 367 a.C. (data da lex Licinia de magistratihus, que possibilitou o acesso dos plebeus à magistratura maior do Consulado).

É esta a época marcada historicamente por:

a) rebeliões da plebe (secessiones plebis) e sua acirrada luta e vitória política contra os patricios;

b) vitória de Roma sobre toda península itálica e, em suguida, sobre quase todo o continente europeu e inteira bacia do Mediterrâneo (guerras púnicas e destruição de ('artago);

c) acentuação das diferenças entre ricos e pobres, com o surgimento dos latifúndios e desaparecimento da classe média rural, dando origem à guerra civil de cem anos desencadeada pelas propostas legislativas dos irmãos Graco (fases principais desta guerra foram: a democratização de Ruma por Mário, com a criação de um exército profissional, a contra-revolução do Senado sob Sila, a guerra contra os aliados que exigiam a cidadania romana, as rebeliões dos escravos (Espartaco) e de Catilina, e, finalmunte, a luta entre os grandes líderes militares, com as alianças tumporárias entre alguns deles). 
Com a conquista da Itália e de toda a região do Mediterrânco, tornou-se necessário, a partir c durante a República, proceder-se à organização territorial desta imensa área conquistada.

A parte central da península itálica, ou seja, o ager romamus, permaneceu sob poder imediato de Roma.

Com os outros povos do resto da Itália, os romanos celebraram tratados, reservando para Roma o total controle dos assuntos militares e de política externa, bem como da arrecadação dos impostos. Em contrapartida, os romanos, com grande astúcia política (ao contrário do verificado por alguns impérios do mundo moderno e atual), garantiam aos povos vencidos completa liberdade de organização da vida política interna, do direito local e do tipo de religião, não interferindo em quaisquer destas áreas.

Ainda na Itália, Roma cria várias colônias, mandando para ali emigrantes romanos, principalmente ex-soldados ou legionários aposentados.

Fora da Itália, são organizadas as províncias, estando Roma representada por um administrador romano (Pró-Cônsul ou Pró-Prctor), também chamado Governador, nomeado para mandato de um ano.

Esta complicada organização territorial, portanto, apresentava Roma no centro de uma extensa rede de tratados, bases militares e governos provinciais.

Com o aumento das complexidades de gerenciamento deste imenso território, a par de problemas como a corrupção reinante nos governos provinciais, este modelo de organização territorial, centrado na idéia da polis ou Estado-cidade, mostra-se cada vez mais inadequado.

Será então apenas depois da República, com o Principado ou Alto Império, que a organização territorial encontrará um modelo de gestão mais satisfatório, de modo a atender as necessidades de administração de uma área tão grande.

\subsection{Constituição politica}

No tocante à Constituição Política da Roma republicana, estruturava-se ela em uma forma de governo baseada no poder executivo-administrativo-judiciário das Magistraturas, eleitas pelas Assembléius Populares e controladas politicamente pelo Senado.

Eram estes, portanto, os três órgãos de governo.

Com o início da República, ou melhor, paulatinamente (como se disse acima). o Rei foi substituido pelo pontifex maximus em relação às suas funções religiosas.

Já no tocante às suas atribuições militares e administrativo-judiciárias, por dois co-chefes de governo, chamado Cônsules, eleitos pelos Comícios por Cientúrias, com mandato 
de um ano (chamados, por isto mesmo, "Magistrados Epônimos" vale dizer, cujos nomes serviam para designar os anos, pois não havia ainda, obviamente, a simples numeração progressiva "antes de Cristo" e "depois de (risto").

O Consulado, primeira espécie, portanto, de Magistratura, concentrava o mando militar do exército, o controle da polícia interna e da segurança pública, o gerenciamento dos serviços estatais e do funcionalismo público, a gestão do erário ou tesouro público, e. finalmente. a administração da justiça e o exercício da atividade jurisdicional.

Percebe-se, claramente. já o problema representado pelo acúmulo excessivo de atribuições, as quais, com o progresso de Roma e a conquista de novos territórios, assumem contornos de sempre maior complexidade.

Por outro lado, eram constantes as ausências dos Cônsules no centro do poder, empenhados fora de Roma no comando do exército nas guerras, o que gerava várias dificuldades. Além disto a plebe, por intermédio de uma acirrada luta política, pressionava pela obtenção de poder, concentrado nas mãos dos Cônsules-patrícios.

Com tudo isto, é evidente que os Cônsules, para o exercício daquelas inúmeras atribuições, e por pressão política, foram obrigados paulatinamente a delegar poderes.

Assim, o Consulado é desmembrado. surgindo. pouco a pouco, uma série de novas Magistraturas.

Foram elas, principalmente:

a) A Questura, para a gestão das finanças públicas.

b) A Censura. para recensear a população romana, descrevendo c fixando a relação de bens e o patrimônio de cada chefe ou paterfamilias, de modo a atender finalidades fiscais e políticas (cobrança dos impostos e organização das listas de eleitores nas Assembléias Populares); tinha também competência financeira, homologando contratos para a realização de obras públicas.

c) A Preturu. para administrar a justiça em matéria (fundamentalmente) civil. dirimindo conflitos entre romanos (praetor urbanus) ou entre romanos e estrangeiros ou só entre estes (praetor peregrinus).

d) A Edilidade, para a fiscalização e regulamentação das atividades comerciais ou relações de consumo nos mercados (como, por exemplo, a estipulação dos procedimentos e regras em caso de vícios redibitórios nos contratos de compra-e-venda).

e) A Ditadura, para o controle das graves situações de atentado contra a segurança do Fstado romano.

f) O Trihunato da Plebe magistratura plebéia de enorme poder políticn, para o controle e veto de quaisquer atos ou deliberações das Magistraturas patrícias acima citadas.

Note-se que tais "Magistrados", na Constituição Política da República romana. 
eram portanto, grosso modo, a reunião, em uma só pessoa, das figuras de administrador público, parlamentar eleito, e também juiz de Direito (já que, neste aspecto, a administração da justiça não era uma exclusividade dos Pretores).

Como características, em geral, das Magistraturas republicanas, costuma-se apontar principalmente:

1) Titularidade de amplos poderes político-constifucionais, consubstanciados nas chamadas "potestas" e no "imperium" A primeira consistia no papel de representação do Estado romano, gerando-lhe direitos e obrigações. O segundo, por sua vez, assentava-se na personificação do poder supremo do Estado sobre os seus cidadãos, representado pelo comando do exército, pelu dominio da iniciativa legislativa (proposta de leis), e pelo controle e administração das justiças civil e criminal.

2) Disponibilidade do famoso instrumento representado pela "intercessio". Era o poder de veto recíproco entre os magistrados contra quaisquer suas deliberações, gerando uma interessante figura de condomínio ou copropricdade do poder político-constitucional, ao forçar sempre um acordo ou colaboração entre eles no comum exercício do poder executivo.

3) Limitação de poderes no âmbito da justiça criminal. Tal se dava pela concessão a qualquer cidadão da também bastante conhecida provocatio ad populum, espécie de recurso ou apelação à Assembléia Popular contra sentença de condenação à morte ou multa proferida por qualquer Magistrado.

O segundo órgão de governo da Constituição republicana era aquele representado pela Assembléias Populares.

Durante a época republicana, encontramos quatro tipos de Assembléias Populares: a) Comicios por (úrias (comitia curiata): b) Comícios por Centúrias (comitia centuriata): c) Comícios por Tribos (comitia tributa): e d) Comícios da Plebe (concilia plebis).

Os Comícios por Cúrias subexistiram, mantendo as mesmas funções políticoadministrativas já exercidas (e já acima mencionadas) durante a Realeza.

Ao lado destes últimos, surgem ou se firmam os Comícios por Centurias, com a divisão do povo em grupos conforme a riqueza ou fortuna pessoal de cada um.

Tinham atribuições eleitorais, na escolha das magistraturas maiores (Censura, Pretura, Ditadura, e Consulado), judiciário-penais, na apreciação da apelação penal extrema (provocatio ad populum) contra sentença de morte, e legislativas, participando do processo de formação das leis, através de sua votação e aprovação (sem, contudo, dircito de iniciativa de proposta de leis ou de emenda legal).

Por sua vez, aparecem, nesta época, os Comicios por Tribos, que sc baseavam em uma div isão territorial de grupos de cidadãos em conformidade com o domicílio de cada um. 
Apresentavam atribuiçõ's eleitorais, na escolha das magistraturas menores (Fdilidade e Questura), judiciárias, na apreciação da provocatio ad populum um caso de condenação a multa superior a 3.020 asses, e legislativas, na votação de leis em geral, substituindo pouco a pouco a competência dos comícios por centúrias neste mister legisferante.

Finalmente, como última espécie de Assembléia Popular na República, encontramos os famosos Comicios da Plebc.

Estes, durante o período republicano, adquirem enorme força política em seguida a uma acirrada luta e retumbante vitória política contra o patriciado. como veremos mais abaixo. Nestes comicios, ao contrário dos outros. só podiam votar os plebeus, convocados pelo Tribuno da Plebc.

Tinham funções eleitorais, na eleição dos seus Magistrados (Tribunos da Plebe), judiciárias, na apreciação, em grau de apelação, das multas impostas pelos Tribunos, e legislativas, na votação de suas leis, chamadas plebiscitos.

O terceiro e último órgão de governo da Constituição republicana era representado pelo Senado.

Manteve ele durante a República sua importante função consultiva, já presente na Realeza defronte ao Rei. e agora em relação aos Magistrados. Baluarte das tradições romanas, era integrado por famosos, ilustres e experientes ex-Magistrados nomeados pelos Cônsules.

Constituía-se, deste modo, em um órgão de grande prestígio social e político, e. por conseqüência, um verdadciro centro de poder. apesar de, a rigor e em teoria, não possuir, constitucionalmente, amplas atribuições executivas. Tinha também certa função legislativa, devendo confirmar as leis votadas nos Comícios.

Na prática, contudo, o Senado participava, de fato, ativamente da administração do Erário e das finanças públicas (também em razão de o mandato dos Magistradosadministradores ser curto. apenas um ano), bem como da condução da política exterior e do gerenciamento de algumas províncias.

A importância politica do Senado, aliás, reflete-se na famosa fórmula oficial pela qual se passou a simbolizar a República romana: "S.P.Q.R." - Senarus Populusque Romanus (Senado e Povo Romano).

Percebe-se, pois, da análise dos três órgãos de govemo da República (Magistraturas, Assembléias Populares e Senado), a presença na Constituição republicana. como notam alguns estudiosos, de um interessantíssimo "sistema de freios e contrapesos": o formalmente ilimitado poder executivo-administrativo-judiciário das Magistraturas patrícias era restringido pelo direito de veto (intercessio) atribuido reciprocamente entre os mesmos 
magistrados, ¿ pela garantia constitucional a qualquer pessoa do povo de recurso penal às Assembléias Populares (provocatio ad populum), tudo harmonizado e atenuado, de um lado, primeiramente, pela liderança política do Sunado, e de outro, e em seguida, pela força político-constitucional da Plebe e de sua Magistratura (Tribunato).

A esta altura, poder-se-ia até perguntar até que ponto a Constituição republicana poderia corresponder a um exemplo de Democracia, na maneira como entendida modernamente.

Pode-se logo dizer que a grandeza da Ruma republicana, no seu modelo político-constitucional. pouco deixa a dever quando comparada a uma democracia no suntido moderno (Margadant).

O já referido sistema político-constitucional de controles e contrapesos ("checks and balances"), representado pelo poder de veto (intercessio), pela necessidade de colaboração, no procısso de formação das leis, entre Magistratura, Assembléias Populares e Senado, pelo papel da Censura e da opinião pública, pelo tradicionalismo arraigado. pela garantia dos direitos fundamentais representada pela provocatio ad populum, e pelo fato de muitas funções executivas serem apenas anuais. colegiadas e haseadas na eleição popular, configurariam possivelmente um verdadeiro Estado democrático ou algo muito próximo a tal modelo de governo na acepção moderna.

Não nos parece procedente a crítica de alguns, ao referir que nas Assembléias Populares romanas inexistiria democracia, já que, como veremos mais adiante, quando do exame da estrutura constitucional das votações, o scu controle caia sempre nas mãos das classes mais ricas.

Em primeiro lugar: também em muitas "democracias" do mundo moderno, ainda hojc. de uma maneira ou de outra, a liderança acaba por residir ou dirctamente nas mãos dos representantes das classes mais abastadas. ou indiretamente, na esfera dos influentes líderes políticos democráticos, freqüentemente representados pelos filhos rebeldes das mesmas classes mais ricas.

Em segundo lugar, se fosse, aliás, válida tal critica, alguns sistemas políticoconstitucionais modemos de eleição (como, por exemplo, o brasileiro) estariam clesqualificados como "democracias" tendo em vista a fundamental importância exercida pelo poder econômico nos processos eleitorais.

Ao sc recordar aqui o ideal de democracia, e, por conseguinte, a aspiração de igualdade de direitos e de mesmas oportunidades entre as pessoas, não podemos, a esta altura, deixar de nos reportar, ainda que perfunctoriamente, à intensa e heróica luta politica e de classes entre os plebeus e os patrícios.

Com a instalação ca República c' a expulsão dos Reis de Roma, os plebeus, 
protegidos destes últimos, sentiram-se indefesos diante do novo centro de poder politico representado. de uma parte. pelo Senado e, de outra. pelas nascentes novas magistraturas que surgiam, ambos os órgãos integrados apenas, como se disse de início, pelos patrícios.

Ao mesmo tempo, agravavam-se cada vez mais as desigualdades sociais e de direitos entre as duas classes, apesar da existência entre os plebeus, principalmente entre as suas lideranças, de vários novos-ricos.

Intensificando-se a luti, através de greves e secessões, e com a retirada dos plebeus para o Monte Sagrado (atual Colina do Aventino), o Senado, não resistindo à pressão política. começa a ceder.

Agripa então, representante do Senado, após, segundo as fontes, ter pronunciado um famoso discurso de reconciliação (com a equiparação da secessão da plebe à revolta dos membros de um corpo contra o seu estômago, considerado por alguns como precursor do organicismo sociológico), sela acordo com a plebe.

No entanto, como contrapartida neste acordo, a plebe exige e obtém o dircito de ter um seu representante - o famoso Tribuno da Plebe - , o qual, constitucionalmente. passa a ser considerado "sacrosanto" vale dizer, inviolável e munido do poder geral de veto. Com isto, torna-se tal Magistratura plebéia um centro de poder na vida política da antiga Roma.

Em seguida, paulatinamente, a plebe vai conseguindo sucessivas e importantes vitórias.

De um lado. na vida privado-jurídica, pressiona e obtém a primeira ('odificação (Lei das XII Tábuas), com a conseqüente eliminação da incerteza do direito (consuetudinário). arma nas mãos dos patrícios, bem como alcança a pernissão do matrimônio entre membros das duas classes.

De outro, na vida político-administrativa, consegue, primeiro, a equiparação de suas leis (plebiscitum) àquelas dos patrícios (lex), e em seguida, o acesso ao Senado e ao poder executivo, mediante sua admissão pouco a pouco nas várias Magistraturas (Consulado e Questura, a partir de 367 a.C.; Edilidade, desde 366; Ditadura, a partir de 356 a.C.; Censura, desde 351 a.C.; Pretura, a partir de 337 a.C.; por fim, e fora das Magistraturas, o Sacerdócio, desde 300 a.C.).

Assim. por volta de meados do século III a.C., chega-se, constitucionalmente, a uma equiparação completa de todos os direitos entre patrícios e plebeus.

No entanto, concomitantemente com o paulatino desaparecimento das diferenças entre patrícios e plebeus, uma nova luta de classes se apresenta (Margadant).

De um lado, mais uma vez, os ricos ¿ poderosos (optimales), compostos não só pelos antigos patrícios mas agora também pelos plebeus novos-ricos, todos conservadores, e, de outro lado, os pobres e desamparados, liderados por progressistas e socialistas. 
Com isto, como às vezes sóe acontecer até hoje, antigas lideranças (no caso, os plebeus novos-ricos) da massa proletária, após dela servirem-se na luta contra a classe dominante anterior, tornam-se por sua vez, ao alcançar o poder, uma nova oligarquia ou classe dominante, restando o povo humilde novamente desamparado.

É a conhecida equação político-sociológica algumas vezes ainda identificável nos dias atuais.

Nesta nova luta de resistência e pela igualdade de direitos entre os optimales e as classes menos favorecidas. são estes últimos muitas vezes liderados, em uma segunda fase da história republicana, novamente por alguns ambiciosos filhos rebeldes das próprias famílias mais ricas, em uma estratégia política e de poder também plenamente reconhecível nos dias atuais. No caso destes líderes, originários das classes mais altas, resta a dúvida sobre se tal opção era impulsionada pelo idealismo, ou se, na verdade, buscava-se apenas maior autoridade e prestígio, já que, para eles, no aspecto pessoal, não se apresentava o problema da luta pelo acesso ao poder econômico-político das classes dominantes.

O Senado, por sua vez, vai perdendo, junto à massa, aquele papel de elemento de referência das tradições e do orgulho do povo romano.

Converte-se, por fim, em uma simples elite dominante, passando, por isto mesmo, a ser combatida. O centro do poder se desintegrava.

É neste quadro que. a partir de Júlio César, vão surgir os vários césares, novo centro de poder, mas agora também um novo referencial e uma nova fonte de inspiração do povo romano.

Começa o Principado ou Alto Império.

São Paulo, dezembro de 2005. 